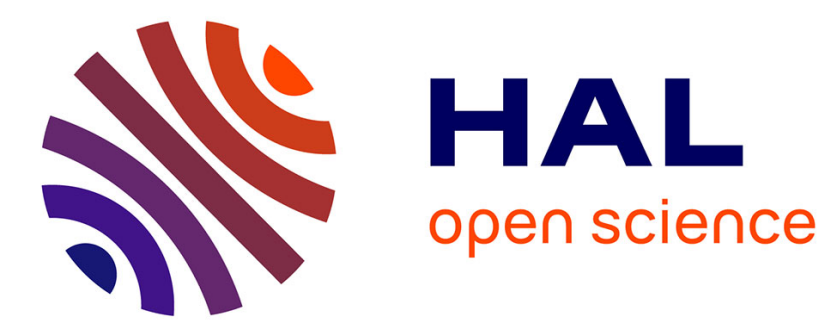

\title{
Radical scavenging, antioxidant and antimicrobial activities of halophytic species
}

\author{
Laetitia Meot-Duros, Gaëtan Le Floch, Christian Magné
}

\section{To cite this version:}

Laetitia Meot-Duros, Gaëtan Le Floch, Christian Magné. Radical scavenging, antioxidant and antimicrobial activities of halophytic species. Journal of Ethnopharmacology, 2008, 116 (2), pp.258-262. 10.1016/j.jep.2007.11.024 . hal-00554858

\section{HAL Id: hal-00554858 \\ https://hal.univ-brest.fr/hal-00554858}

Submitted on 11 Jan 2011

HAL is a multi-disciplinary open access archive for the deposit and dissemination of scientific research documents, whether they are published or not. The documents may come from teaching and research institutions in France or abroad, or from public or private research centers.
L'archive ouverte pluridisciplinaire HAL, est destinée au dépôt et à la diffusion de documents scientifiques de niveau recherche, publiés ou non, émanant des établissements d'enseignement et de recherche français ou étrangers, des laboratoires publics ou privés. 


\section{Radical scavenging, antioxidant and antimicrobial activities of halophytic species}

Laetitia Meot-Duros $^{\mathrm{a}^{*}}$, Gaëtan Le Floch ${ }^{\mathrm{b}}$ and Christian Magné $\mathrm{a}^{\mathrm{a}^{*}}$

${ }^{\text {a }}$ Laboratoire d'Ecophysiologie et de Biotechnologie des Halophytes et des Algues Marines, EA 3877 (LEBHAM), Institut Universitaire Européen de la Mer, Université de Bretagne Occidentale, Technopôle Brest Iroise, Place Nicolas Copernic, 29280 Plouzané, France

${ }^{\mathrm{b}}$ Laboratoire de Biodiversité et d'Ecologie Microbienne, EA 3882, ESMISAB, Université de Bretagne Occidentale, Technopôle Brest-Iroise, 29280 Plouzané, France

* authors for correspondence: laetitia.meot@univ-brest.fr \& christian.magne@ univ-brest.fr Tel: +33 (0)2 984986 69; Fax: +33 (0)2 98498772

Keywords: Eryngium maritimum, Cakile maritima, Crithmum maritimum, antimicrobial, antioxidant, phenol content

Abbreviations: ABTS: 2, 2'-azinobis (3-ethylbenzothiazoline-6-sulfonic acid); ATCC: American Type Culture Collection; BCC: Brittany Culture Collection; GAE: Gallic Acid Equivalents; TAC: Total Antioxidant Capacity. 


\section{Introduction}

Food poisoning is still a concern for both consumers and the food industry despite the use of various preservation methods. Because of the resistance that pathogens build against antibiotics, there is a growing interest to use natural antibacterial products for food preservation, like extracts of herbs and spices (Smid and Gorris, 1999). Indeed, natural crude extracts and biologically active compounds from plant species used in traditional medicine may represent valuable sources for such new preservatives (Al-Fatimi et al., 2007).

Eryngium maritimum L. (sea holly, Apiaceae), Crithmum maritimum L. (sea fennel, Apiaceae) and Cakile maritima Scop. (sea rocket, Brassicaceae) are three halophytic species commonly found along Atlantic coast. They generally grow in sand hills, sea fennel being also found in rocky cliffs. These halophytes have found many applications in folk medicine. Thus, C. maritimum and C. maritima are thought to have diuretic, antiscorbutic, digestive and purgative properties (Guil Guerrero et al., 1996; Davy et al., 2006). Various properties were traditionally attributed to sea rocket. Indeed, this emetic plant was good to cleanse the lungs of tough viscid phlegm, could help jaundice and dropsy, and was prescribed in scrofulous affections and lymphatic disturbances (www.herbnet.com). Sellam et al. (2007) described antifungal activity of phytoalexins and glucosinolates, two natural compounds present in Cakile maritima. Antimicrobial activity was also proved in other Brassicaceae (Sekiyama et al., 1996 ; Brown and Morra, 1995). E. maritimum has numerous medicinal uses as a diaphoretic, a diuretic, a stimulant, a cystotonic, a urethritis remedy, a stone inhibitor, an aphrodisiac, an expectorant and as an anthelmintic (www.botanicals.com, www.crescentbloom.com). However, literature on possible activities of sea holly only highlights anti-inflammatory and antinociceptive properties (Küpeli et al., 2006). Studies on antioxydant or antibiotic properties of these halophytes mainly deal with sea fennel essential oil (Ozcan, 2000; Ruberto et al., 2000). Sea rocket was recently studied for its radical 
scavenging activity (Ksouri et al., 2006), but no antimicrobial properties have been scientifically demonstrated.

In the present work, we report for the first time the results of the combined investigations on in vitro antibacterial, radical scavenging and antioxidant activities of the extracts of these three halophytic species, with the aim of demonstrating their biological activities and confirming their potential as natural preservatives.

\section{Materials and methods}

\subsection{Plant material}

Leaves of Crithmum maritimum L., Eryngium maritimum L. and Cakile maritima Scop. were collected along the shoreline at "Pointe du Toulinguet" (Brittany, France) in August 2006. The leaves were cleaned with deionized water, rapidly soaked, stored at $-25^{\circ} \mathrm{C}$ and then freeze dried. The dry material was ground to a fine powder.

\subsection{Extraction of plant material}

For the determination of total phenol contents and antioxidant activities, $200 \mathrm{mg}$ of powder were homogenized with $5 \mathrm{ml}$ water-methanol $(1: 1)$ under magnetic stirring at $4^{\circ} \mathrm{C}$ for $20 \mathrm{~min}$. After centrifugation for $15 \mathrm{~min}\left(4^{\circ} \mathrm{C}, 4000 \mathrm{~g}\right)$, the resulting pellet was extracted twice following the same protocol. The supernatants were collected, pooled and filtrated over glass wool. The obtained extract was concentrated by rotary evaporation at $30^{\circ} \mathrm{C}$. The residue was dissolved in deionized water.

For the antibacterial tests, $200 \mathrm{mg}$ of powder were homogenized with $5 \mathrm{ml}$ methanolchloroform-water (12:5:3) under magnetic stirring for $20 \mathrm{~min}$. As mentioned previously, three successive extractions were performed. After phase separation by adding deionized water, chloroformic and aqueous fractions were concentrated by rotary evaporation at $30^{\circ} \mathrm{C}$. The 
residues were weighed and dissolved in methanol to a concentration of $10 \mathrm{mg} \cdot \mathrm{ml}^{-1}$ and $2 \mathrm{mg} \cdot \mathrm{ml}^{-1}$ for the polar and apolar phases, respectively.

\subsection{Chemicals}

Folin-Ciocalteu reagent, 2,2'-azinobis-(3-ethylbenzothiazoline-6-sulfonic acid) (ABTS), potassium persulfate, sodium phosphate and ammonium molybdate were purchased from Sigma-Aldrich. Methanol and chloroform were from Carlo Erba Reagenti. All other reagents were of analytical grade.

\subsection{Microorganisms}

Antimicrobial activity was tested against a panel of microorganisms, mainly foodborne pathogens as well as clinical isolates (Table 1): gram-positive bacteria (cocci and bacilli), gram-negative bacteria and one yeast. For each type of bacteria, at least one strain was obtained from American Type Culture Collection, all the others were from Brittany Culture Collection. Strains were grown in liquid nutritive broth at $37^{\circ} \mathrm{C}$ overnight before being used for antibacterial activity test.

\subsection{Total phenol content}

The concentration of total phenols in each plant extract was determined with FolinCiocalteu reagent following the colorimetric method adapted by Sanoner et al. (1999). Measurements were carried out in triplicate and calculations were based on a calibration curve obtained with gallic acid. The levels of total phenols were expressed as milligrams of gallic acid equivalents per gram of dry weight (mg GAE.g $\left.{ }^{-1} \mathrm{DW}\right)$. 


\subsection{Scavenging activity of ABTS radical cation}

ABTS radical cation $\left(\mathrm{ABTS}^{*+}\right)$ scavenging activity was measured according to the method described by Re et al. (1999). ABTS was dissolved in water to a $7 \mathrm{mM}$ concentration and the ABTS radical cation was produced by adding potassium persulfate to a final concentration of $2.45 \mathrm{mM}$. The completion of radical generation was obtained in the dark at room temperature for $12-16 \mathrm{~h}$. This solution was then diluted with ethanol to adjust its absorbance at $734 \mathrm{~nm}$ to $0.70 \pm 0.02$. To determine the scavenging activity, $1 \mathrm{ml}$ of diluted $\mathrm{ABTS}^{{ }^{+}}$solution was added to $10 \mu \mathrm{l}$ of plant extract (or water for the control), and the absorbance at $734 \mathrm{~nm}$ was measured 6 min after the initial mixing, using ethanol as the blank. The percentage of inhibition was calculated by the equation:

$$
\text { Inhibition percentage }(\% \mathrm{IP})=\left[\left(\mathrm{A}_{\mathrm{c}}-\mathrm{A}_{\mathrm{s}}\right) / \mathrm{A}_{\mathrm{c}}\right] \times 100
$$

where $\mathrm{A}_{\mathrm{c}}$ and $\mathrm{A}_{\mathrm{s}}$ are the absorbances of the control and of the test sample, respectively. From a plot of concentration against \%IP, a linear regression analysis was performed to determine the $\mathrm{IC}_{50}$ value for each plant extract.

\subsection{Total antioxidant activity}

The total antioxidant capacity (TAC) of the plant extracts was evaluated by the phosphomolybdenum method of Prieto et al. (1999). A $0.1 \mathrm{ml}$ aliquot of the plant extract was mixed with $1 \mathrm{ml}$ of the reagent solution $(0.6 \mathrm{M}$ sulfuric acid, $28 \mathrm{mM}$ sodium phosphate and $4 \mathrm{mM}$ ammonium molybdate). The absorbance of the mixture was measured at $695 \mathrm{~nm}$ and standard curve was performed with ascorbic acid solution. The antioxidant activity of the samples was expressed as milligrams of ascorbic acid equivalents per gram of dry weight. 


\subsection{Antimicrobial activity}

The microplate bioassay (microdilution) was used to study the antimicrobial activities of C. maritimum, E. maritimum and C. maritima. Plant extracts (at the concentration of 1, 2, 10 and $100 \mu \mathrm{g} \cdot \mathrm{ml}^{-1}$ ) were dropped in sterile 96-well plates (NUNC microplate, Fisher Bioblock). Twelve repetitions were made for each concentration. After evaporation of the solvent, $100 \mu$ l of microorganism suspensions $\left(10^{2}\right.$ cells.ml $\left.{ }^{-1}\right)$ were added in wells. Antibiotic solution (mixture of streptomycin and penicillin $\mathrm{G}$ at 5 and $10 \mathrm{mg} \cdot \mathrm{ml}^{-1}$, respectively) was used in the presence of microorganisms for negative control. The microplate was aseptically sealed and incubated at $30^{\circ} \mathrm{C}$ for $24 \mathrm{~h}$. After agitation, microorganism growth was estimated by reading the absorbance in microplate wells at $405 \mathrm{~nm}$ with a microplate spectrophotometer (Multiskan MCC/340, Titertek). The MIC was defined as the lowest concentration of plant extracts able to inhibit microorganism growth. 


\section{Results}

\subsection{Total phenol contents and antioxidant activity}

Sea holly (E. maritimum) exhibited the lowest phenolic content (Table 2), with 30\% and $50 \%$ less phenols than in sea rocket and sea fennel, respectively. Similar observations could be made with the radical scavenging activity. Thus, E. maritimum presented a high ABTS $\mathrm{IC}_{50}$ while $C$. maritimum showed the best radical scavenging activity. Sea rocket, which accumulated a medium level of phenolics, presented quite a strong antiradical activity $\left(\right.$ ABTS $\left.\mathrm{IC}_{50}=0.144 \mathrm{mg} \cdot \mathrm{ml}^{-1}\right)$ and a good antioxidant capacity.

\subsection{Antimicrobial activity}

Table 3 shows MIC of plant extracts against several bacteria and one yeast. Apolar fractions were generally more active compared to polar fraction. Thus, sea holly apolar fraction inhibited 9 microorganisms, whereas its polar fraction only inhibited 2 microorganisms. Listeria monocytogenes was the only bacteria not affected by any of the plant extracts. Conversely, Pseudomonas aeruginosa and P. fluorescens were the most sensitive bacteria to all plants extracts. Indeed, only $1 \mu \mathrm{g} \cdot \mathrm{ml}^{-1}$ of the three polar fractions was necessary to inhibit $P$. aeruginosa growth. Candida albicans was particularly sensitive to the two fractions of sea rocket $\left(1 \mu \mathrm{g} \cdot \mathrm{ml}^{-1}\right)$ as well as Salmonella arizonae with sea fennel extracts (MIC of $1 \mu \mathrm{g} \cdot \mathrm{ml}^{-1}$ ). The average MIC was $100 \mu \mathrm{g} \cdot \mathrm{ml}^{-1}$ for most of bacteria. 


\section{Discussion}

The halophytic plants studied here differed in their capacity to accumulate phenolic compounds. Even if they grew in the same environment, experiencing the same stressful conditions, they produced different patterns of total phenols. Thus, Eryngium maritimum exhibited the lowest phenolic level as well as the lowest radical scavenging activity. Conversely, Crithmum maritimum exhibited the highest total phenol content and ABTS radical scavenging activity. Cakile maritima plants from Brittany coast presented here a lower phenolic level than that measured recently by Ksouri et al. (2006) in several accessions from Tunisia. Although the three halophytic plants differed in their radical scavenging activity and total phenol contents, they presented close antioxidant capacities (32 to $48 \mathrm{mg} \cdot \mathrm{g}^{-1} \mathrm{DW}$ ). Moreover, there was no relationship between total antioxidant and anti-ABTS radical activities. These results can be explained since the global antioxidant property of a plant extract is generally considered as the result of the combined activity of a wide range of compounds including, beside phenolics, peptides, organic acids and other components (Gallardo et al., 2006).

Concerning antimicrobial properties, we report here for the first time antimicrobial activity in both polar and apolar fractions of halophyte extracts. The three halophytes presented a good antimicrobial activity, particularly in their organic (apolar) fraction. Most of the extracts showed a MIC of $100 \mu \mathrm{g} \cdot \mathrm{ml}^{-1}$, some others even being active at $1 \mu \mathrm{g} \cdot \mathrm{ml}^{-1}$. However, they did not show antilisterial activity. That result could be related, in the case of Crithmum maritimum, to the predominance of chlorogenic acid in sea fennel (Meot and Magné, unpublished results) and the absence of antilisterial activity of plant phenolics shown recently for phenolics such as chlorogenic acid (Wen et al., 2003).

Apolar fractions were more active than polar ones. Thus, sea holly polar fraction inhibited the growth of only 2 bacteria, whereas its apolar phase was active against nine 
pathogens. Interestingly, some bacteria were sensitive to both polar and apolar extracts of a same plant (e.g. Salmonella arizonae vs sea fennel, or Pseudomonas fluorescens vs sea holly), though these two fractions greatly differed in chemical composition. Eryngium maritimum presented a strong antibacterial activity against two of the three Pseudomonas species tested (P. aeruginosa and $P$. fluorescens). Indeed, its 2 fractions had low MIC : 1 and $2 \mu \mathrm{g} \cdot \mathrm{ml}^{-1}$ for polar and apolar fractions, respectively. Cakile maritima was very active against Salmonella arizonae (MIC of $1 \mu \mathrm{g} \cdot \mathrm{ml}^{-1}$ for its 2 fractions). Crithmum maritimum had a good antimicrobial activity against Pseudomonas aeruginosa and Candida albicans (MIC of $1 \mu \mathrm{g} \cdot \mathrm{ml}^{-1}$ ).

Sea fennel essential oil was largely studied, both for its antioxidant (Ozcan, 2000) and antibacterial properties (Ruberto et al., 2000). In particular, the latter work reported no antibacterial activity against Pseudomonas aeruginosa and a light activity against Micrococcus luteus, results which were obtained in our chloroform extracts too. However, Ruberto et al. (2000) did not find any activity against Erwinia carotovora and Escherichia coli, suggesting that our positive results were due to molecules not present in essential oil. In another study, Glowniak et al. (2006) presented the activity of sea fennel against Grampositive bacteria. Accordingly, we confirmed that $C$. maritimum apolar fraction inhibited the growth of B. cereus and M. luteus. However, unlike the results of Glowniak et al. (2006), we found activity against $E$. coli, and apolar fraction was inactive against $S$. aureus.

The results of these investigations confirm the capacity of halophytic plants to produce bioactive compounds and the great potential for using them as natural food (or cosmetic) preservatives, as the extracts possess antibacterial and antioxidant activities. The phytochemical characterization of the extracts, as well as the identification of responsible bioactive compounds, is under progress in our laboratory to reinforce the notion of a potent valorization of such plant extracts. 


\section{Acknowledgements}

This research was partly supported by the Brest Metropole Oceane (BMO) through a Ph.D fellowship (L.M.). 
Table 1: Bacterial strains and yeast used in this study.

\begin{tabular}{|c|c|c|}
\hline $\begin{array}{l}\text { Organism or gram } \\
\text { morphology and strain }\end{array}$ & Species & $\begin{array}{l}\text { Culture Collection } \\
\text { identification } \\
\text { number }\end{array}$ \\
\hline \multicolumn{3}{|l|}{ Cocci } \\
\hline \multirow[t]{2}{*}{ gram positive } & Staphylococcus aureus subsp. aureus & ATCC, 33862 \\
\hline & Micrococcus luteus & ATCC, 10240 \\
\hline \multicolumn{3}{|l|}{ Bacilli } \\
\hline \multirow[t]{2}{*}{ gram positive } & Listeria monocytogenes & ATCC, 19112 \\
\hline & Bacillus cereus & $\mathrm{BCC}$ \\
\hline \multirow[t]{7}{*}{ gram negative } & Salmonella enterica subsp. arizonae & ATCC, 13314 \\
\hline & Salmonella enterica subsp. montevideo & $\mathrm{BCC}$ \\
\hline & Pseudomonas aeruginosa & $\mathrm{BCC}$ \\
\hline & Pseudomonas fluorescens & $\mathrm{BCC}$ \\
\hline & Pseudomonas marginalis & $\mathrm{BCC}$ \\
\hline & Escherichia coli & $\mathrm{BCC}$ \\
\hline & Erwinia carotovora subsp. carotovora & $\mathrm{BCC}$ \\
\hline Yeast & Candida albicans & $\mathrm{BCC}$ \\
\hline
\end{tabular}


Table 2

Phenolic contents, free radical scavenging activity (ABTS) and total antioxidant capacity (TAC) of polar fractions of plant leaf extracts.

\begin{tabular}{|c|c|c|c|}
\hline & $\begin{array}{c}\text { Total phenol content } \\
\left(\mathrm{mg} . \mathrm{g}^{-1} \mathrm{DW}\right)\end{array}$ & $\operatorname{ABTS~IC}_{50} \cdot\left(\mathrm{mg} \cdot \mathrm{ml}^{-1}\right)$ & TAC (mg.g $\left.{ }^{-1} \mathrm{DW}\right)$ \\
\hline Eryngium maritimum & $16.44 \pm 0.30$ & $0.28 \pm 0.020$ & $32.74 \pm 1.11$ \\
\hline Crithmum maritimum & $31.93 \pm 2.03$ & $0.11 \pm 0.004$ & $39.46 \pm 1.78$ \\
\hline Cakile maritima & $22.24 \pm 0.84$ & $0.14 \pm 0.004$ & $48.64 \pm 2.27$ \\
\hline
\end{tabular}


Table 3.

Antimicrobial activity of plant extracts expressed as minimum inhibitory concentrations (MICs) in $\mu \mathrm{g} \cdot \mathrm{ml}^{-1}$

\begin{tabular}{|l|cc|cc|cc|}
\hline \multirow{2}{*}{ Bacteria strains } & \multicolumn{5}{|c|}{ MIC $\left(\mu \mathrm{gg.ml}{ }^{-1}\right)$} \\
\cline { 2 - 7 } & Eryngium maritimum & Crithmum maritimum & \multicolumn{2}{c|}{ Cakile maritima } \\
\cline { 2 - 7 } & Polar & Apolar & Polar & Apolar & Polar & Apolar \\
\hline Staphylococcus aureus ATCC 33862 & - & 10 & - & - & - & 100 \\
Listeria monocytogenes ATCC 19112 & - & - & - & - & - & - \\
Micrococcus luteus ATCC 10240 & - & 100 & - & 1 & - & 100 \\
Salmonella arizonae ATCC 13314 & - & 100 & 1 & 1 & - & 10 \\
Salmonella montevideo & - & 100 & - & - & - & 100 \\
Erwinia carotovora & - & 100 & - & 100 & - & 100 \\
Pseudomonas marginalis & - & - & 100 & 100 & 2 & 100 \\
Pseudomonas aeruginosa & 1 & 2 & 1 & - & 1 & - \\
Pseudomonas fluorescens & 1 & 2 & 1 & 100 & - & - \\
Escherichia coli & - & - & - & 100 & - & 100 \\
Bacillus cereus & - & 1 & - & 10 & - & 1 \\
Candida albicans & - & 100 & - & 10 & 1 & \\
\end{tabular}




\section{References}

Al-Fatimi, M., Wurster, M., Schroder, G., Lindequist, U., 2007. Antioxidant, antimicrobial and cytotoxic activities of selected medicinal plants from Yemen. Journal of Ethnopharmacology 111, 657-666.

Brown, P.D., Morra, M.J., 1995. Glucosinolate-containing plant tissues as bioherbicides. Journal of Agricultural Food Chemistry 43, 3070-3074.

Davy, A.J., Scott, R., Cordazzo, C.V., 2006. Biological flora of the British Isles: Cakile maritima Scop. Journal of Ecology 94, 695-711.

Gallardo, C., Jimenez, L., Garcia-Conesa, M.-T., 2006. Hydroxycinnamic acid composition and in vitro antioxidant activity of selected grain fractions. Food Chemistry 99, 455463.

Glowniak, P., Los, R., Skalicka-Wozniak, K., Widelski, J., Burczyk, J., Malm, A., 2006. Activity of Crithmum maritimum L. (Apiaceae) against Gram-positive bacteria. Annales Universitatis Mariae Curie-Sklodowska Lublin, Polonia 19, 123-127.

Guil-Guerrero, J.L., Torija Isana, M.E., Gimenez Martinez, J.J., 1996. Composicion nutricional del hinojo marino (Crithmum maritimum L.). Alimentaria 34, 65-72.

Ksouri, R., Megdiche, W., Debez, A., Falleh, H., Grignon, C., Abdelly, C., 2007. Salinity effects on polyphenol content and antioxidant activities in leaves of the halophyte Cakile maritima. Plant Physiology and Biochemistry 45, 244-249.

Küpeli, E., Kartal, M., Aslan, S., Yesilada, E., 2006. Comparative evaluation of the antiinflammatory and antinociceptive activity of Turkish Eryngium species. Journal of Ethnopharmacology 107, 32-37.

Ozcan, M., 2000. Antioxydant activity of sea fennel (Crithmum maritimum L.) essential oil and rose (Rosa canina) extract on natural olive oil. Acta Alimentaria 29, 377-384.

Prieto, P., Pineda, M., Aguilar, M., 1999. Spectrophotometric quantitation of antioxidant 
capacity through the formation of a phosphomolybdenum complex: specific application to the determination of vitamin E. Analytical Biochemistry 269, 337-341.

Re, R., Pellegrini, N., Proteggente, A., Pannala, A., Yang, M., Rice-Evans, C., 1999. Antioxidant activity applying an improved ABTS radical cation decolorization assay. Free Radical Biology and Medicine 26, 1231-1237.

Ruberto, G., Baratta, M.T., Deans, S.G., Dorman, H.J.D., 2000. Antioxidant and antimicrobial activity of Foeniculum vulgare and Crithmum maritimum essentials oils. Planta medica 66, 687-693.

Sanoner, P., Guyot, S., Marnet, N., Molle, D., Drilleau, J.-F., 1999. Polyphenol profiles of French cider apple varieties (Malus domestica sp.). Journal of Agricultural and Food Chemistry 47, 4847-4853.

Sekiyama, Y., Mizukami, Y., Takada, A., Oosono, M., Nishimura, T., 1996. Effect of mustard extract vapor on fungi and spore-forming bacteria. Journal of Antibacterial and Antifungal Agents 24, 171-178.

Sellam, A., Iacomi-Vasilescu, B., Hudhomme, P., Simoneau, P., 2007. In vitro antifungal activity of brassinin, camalexin and two isothiocyanates against the crucifer pathogens Alternaria brassicicola and Alternaria brassicae. Plant Pathology 56, 296-301.

Smid, E.J., Gorris, L.G.M., 1999. Natural antimicrobials for food preservation. In: M. Shaurr Rahman, Editor, Handbook of food preservation, Marcel Dekker, New York, pp. 285308.

Wen, A., Delaquis, P., Stanich, K., Toivonen, P., 2003. Antilisterial activity of selected phenolic acids. Food Microbiology 20, 305-311.

www.botanicals.com

www.crescentbloom.com

www.herbnet.com 